\title{
THE USE OF AI (ARTIFICIAL INTELLIGENCE) IN ENGLISH LEARNING AMONG UNIVERSITY STUDENT: CASE STUDY IN ENGLISH DEPARTMENT, UNIVERSITAS AIRLANGGA
}

\author{
Hemas Kumala Dewi ${ }^{1}$, Nur Annisa Rahim ${ }^{2}$, Raselly Elfa Putri ${ }^{3}$, Tia Ivanka Wardani ${ }^{4}$, Moses Glorino Rumambo \\ Pandin $^{5 *}$ \\ ${ }^{12345}$ English Department, Faculty of Humanities, Universitas Airlangga, Surabaya, Indonesia
}

\author{
*Corresponding Author: \\ Moses Glorino Rumambo Pandin \\ Faculty of Humanities, Universitas Airlangga \\ Jl. Dharmawangsa Dalam Selatan, Kampus B, Surabaya, 60286 \\ moses.glorino@fib.unair.ac.id
}

\begin{abstract}
Aim: This research aim is to analyze an artificial intelligence platform that can be used in imparting education as well as evaluating student performance. Method: This research was conducted with a qualitative method by conducting in-depth interviews and a literature study. Results: The findings of this study shows that Artificial Intelligence technology can be used as a means of developing English learning for students. Discussion: There have been several studies that support research results, that AI can be used to improve students' English skills through applications, websites, Virtual Reality technology, and other AI-based learning and teaching systems. Limitation: The limitation of this research is that it does not examine how far the role of AI in students' English learning is. Suggestion: For further research, it is expected to test how far the role of AI is to improve students' English skills, especially Universitas Airlangga students.
\end{abstract}

Keywords: artificial intelligence, English language, English skills, higher education, online learning.

\section{INTRODUCTION}

The PC will solely method 0s and 1s. However, a couple of years ago, artificial intelligence (AI) was dedicated to supplying the power to make computers become learning media. This can the primary computer expert goal like Alan Mathison Turing, John von Neumann, and Norbert Wiener, with the principle of modeling the human brain, mimicking human learning, and simulating biological evolution [1][2][3]. In addition, info exchange uses the most recent information and communication technology (ICT), knowledge networks, actuators, sensors, and automatic identification and material pursuit technology referred to as machine learning (ML) are established [4]. ML is an AI application that enables you to mechanically learn and improve from experience, notwithstanding the system isn't expressly programmed. Machine learning focuses on developing pc programs that will access and learn knowledge independently. Machines play a very important role in assembling library resources and user services. Robotics, chatbots, text data processing (TDM), massive data, and pattern recognition are samples of machine learning tools among AI [5]. 
Artificial intelligence has been used as a powerful tool in education. Several analysis studies are projected on pedagogy victimization artificial intelligence. Education is advancing additional and more with the help of computer science. victimization artificial intelligence technology, lecturers will mechanically analyze the tutorial method. In addition, pedagogy seems to possess been improved by the mixing of artificial intelligence technology [6][7]. Science communication faces analysis dissemination through research publications and different methods. This includes original research, growing ideas, diffusing, and disseminating research results. analysis exhausted all disciplines must be effectively disseminated to achieve influence and a broader perspective [8][9]

Learning is the process of improving knowledge. By taking part in an exceedingly explicit exercise, every learner bit by bit shifts from a beginner to the main target of the following area. within the practice of participation, learners convey their experiences and social experiences through a range of direct and indirect ways in order to develop sensible skills and acknowledge their values [10][11]. Due to the need for English as a universal language, its utility becomes more and more important, particularly in countries where English could be a second language. Hence, it is necessary to improve the schoolroom surroundings and develop the learner in the simulation language environment [12][13]. Building a man-made intelligence English education system is often used as a breakthrough to facilitate the transformation of contemporary info technology into English education, improve the standard of teachers' English education, and improve student initiatives in learning English. Advances in computer science in language translation and understanding programs have evolved into new ideas for human language processing. Not solely are you able to realize the mistakes created by the coed, however you will additionally mean the mistakes made by the student with the targeted recommendation and research suggestions [14] [15].

The purpose of this work is to research artificial intelligence platforms which will be used each in providing education and assessing student grades. It is often custom-built to satisfy the wants of education Associate in Nursing respect levels. Once developing an AI platform, the foremost vital AI schemes are used such as recognition and pattern matching, deciding and selection, abstract interface and reasoning, execution and flow control, coming up with and downside solving. value student performance victimization knowledge-based systems and monitored machine learning techniques [9].

\section{METHOD}

In this study, researchers used qualitative research methods. According to [16] qualitative research is a study using a natural background, with the concern of interpreting the recent phenomena by involving various methods such as interviews, observations, and literature review.

This qualitative is conducted with a library study approach and interviews. The method of literature review aims to collect and take the essence of previous research and the results serve as a foundation for various types of research because it provides an understanding of the development of knowledge, sources of policy-making stimulus, triggers the creation of new ideas and is useful as a guide for research in certain fields of research [17]. The study was conducted online through a zoom meeting. 
While the interview method we use is an in-depth interview, digging deeply into one topic that has been determined (based on the purpose and purpose of the interview) using openended questions. This excavation is done to find out their opinions based on the perspective of respondents in looking at a problem. In this study, we wanted to know the perspective of informants on the role of AI in supporting English learning among students.

\section{Data Collection Strategy}

The data was obtained in two ways, namely library studies, and interviews.

The interview process begins by determining

a. Informant

In this study, we determined the informant using a purposive technique, which is a data source sampling technique with certain considerations. The sample is the most relevant person to be sampled.

Some of the informant criteria taken by researchers:

1) UNAIR students

2) Students who are or have used AI for English language learning

3) Informants are willing to be interviewed and involved in the study

b. Drafting questions

Interview questions in this study are developed based on the formulation of the problem and the purpose of the research.

c. Conducting an interview

The interview is conducted face-to-face and lasts for 30-60 minutes. The interview process was recorded through a recorder on a mobile phone.

d. Interview results

The results of the interview recorded via mobile phone are copied and presented in written form.

The method of literature review aims to collect and take the essence of previous research and the results serve as a foundation for various types of research because it provides an understanding of the development of knowledge, sources of policy-making stimulus, triggers the creation of new ideas and is useful as a guide for research in certain fields of research [17].

The literature review is obtained from several main databases, namely Sciencedirect, Pubmed, Garuda, GoogleScholar, Proquest, Web of Science, Taylor \& Francis, Scopus, Springer with a span of years between 2019-2021. The search was conducted with a boolean operator (AND and OR) with the keyword "Artificial Intelligence" "Language learning" "Learning English". 


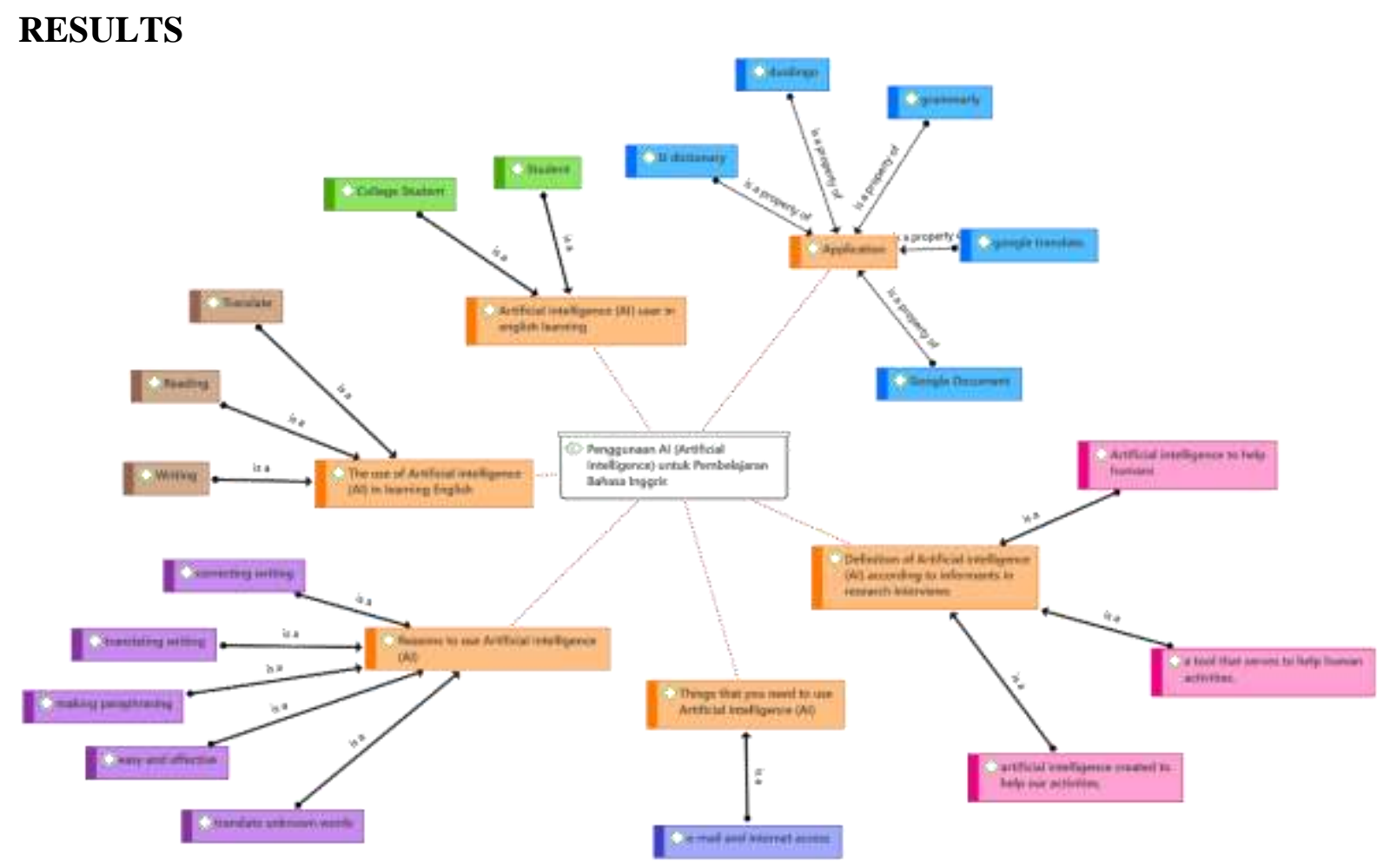

Figure 1: Interview Coding-Analysis

In this section, researchers present the results of the analysis of interview data with coding techniques using the help of ATLAS.ti Software. Researchers conducted interviews to find out how the role of AI (Artificial Intelligence) in learning English in the scope of students during the pandemic.

Based on the results of the interview analysis of informants, students obtained five subjects in this study. The five points of discussion are spelled out as follows:

\section{Definition of AI (Artificial Intelligence) from the perspective of informants}

The majority of informants (students) say that AI is artificial intelligence used to help human activities. Through AI humans will be helped and facilitate the activities they do. In addition, the use of AI can also minimize mobility between humans, so that it can shorten the time to be much more effective. The use of AI that is flexible and easy to reach by anyone makes AI continue to grow to support human life. All activities began to be supported with the help of AI and then became a phenomenon of digitalization.

\section{Things needed in the use of AI}

AI (Artificial Intelligence) is closely related to digitalization. That's because the use of AI in people's lives will be the same as changing the activities carried out into digital activities to make it easier. The use of AI in everyday life needs to be supported by internet facilities. The respondents revealed that the internet became an important facility in the use of AI in people's lives. Through the Internet, we can connect from a long distance and make it easier for us to find all the information we need.

\section{Reasons for using AI (Artificial Intelligence)}

The use of AI (Artificial Intelligence) in English learning is needed. The informants say that the use of AI (Artificial Intelligence) has a positive impact on English language learning. That's because the fast and effective nature of AI can help them in the difficulty 
of learning English, such as searching for words they do not know. In addition, the informants revealed that the utilization of AI (Artificial Intelligence) is more used in writing tasks. Through the help of AI (Artificial Intelligence) respondents said they can do the task much faster than manually without the help of any digital tools. From this, it can be concluded that the use of AI (Artificial Intelligence) has a positive impact on English language learning.

\section{DISCUSSION}

The results showed that Artificial Intelligence technology can be used as a means of developing English learning for students. The interview results showed that students of AIbased applications such as Duolingo, Google Translate [18], and Grammarly can assist them in learning or English assignments in various aspects of skills, ranging from writing, listening, to speaking (especially pronunciation) [18][19][20]. Artificial intelligence with the help of application development can improve the quality of language translation [10]. The effectiveness of the use of AI in training and improving English skills has been done in several studies. In research conducted on Psychology students at Universitas Sarjanawiyata showed that the use of AI-based applications such as Netflix and Joox Music can significantly and effectively improve students' listening skills [21]. In addition, AI can also take the form of chatbots that facilitate communication, to improve one's language skills [22]. Then, in other studies, the use of AI was shown to improve writing skills and lower the fear of writing [23]. Fear in the use of foreign languages, especially speaking to students can cause student achievement scores in learning to decrease. The higher the level of anxiety, the achievement of student scores in foreign language learning will decrease [24].

Then, in research conducted by Noviyanti et al, the use of AI in the form of spell checker application can improve pronunciation skills, the score between pretest and posttest increased by 33 points, from 56 to 90 . So, in the study, it is believed that the use of spell checker applications is effective to improve English pronunciation for self-learning [25]. So it can be concluded that the use of AI-based applications can improve English language skills, especially in speaking [26].

Not only can it use AI-based English applications, but the use of other technologies such as Virtual Reality (VR) can also be one of the mediums that can be used in developing English language learning, Lia Ma's research reveals that integrating constructivism theory and virtual reality technology to educate the immersive context of English college can indeed boost students' English levels. [27]. Then, in other studies, the use of AI in the form of virtual assistants, such as Lyra Virtual Assistant is effective in speaking exercises [28].

The use of AI can not only be used for students' personal learning but can also be developed into teaching methods in general. In the modern English language teaching and learning process, we should not only remain aware of the practice and application of AI in teaching, but also fully integrate AI and English teaching activities and interact effectively, optimize the effects and models of English language teaching, and promote the development of English language education [29]. In English language teaching and learning, AI can provide a real simulation dialogue platform for English language teaching and learning [30]. There have been numerous AI-based teaching systems established, such as DL-OIET, specifically the evaluation of teaching procedures based on deep learning, which is an unavoidable pattern of 
the presence of teaching systems modified using decision tree algorithms. To personalize the impact of students' learning, classification systems are followed to individualize teaching techniques and teach student activities based on their talents. Expert AI system knowledge is creatively applied to English memory and learning processes, which are expressed as multidimensional variables in information points. [3]. Then some systems combine big data, artificial intelligence into the Eco-Environment of English Teaching that is proven to obtain better learning effects and English application capabilities by comparing with traditional methods [31]. The use of artificial intelligence technology in English language teaching will turn the interaction of English language education from passive to active, completely transforming the level of English education available, enabling personalized and diverse education, and establishing a flexible, transparent, and lifelong ecosystem of personal education [32][33].

Then there is also Multimedia English Teaching which has been tested on listening skills, grammar, reading, writing, vocabulary, and student observations that show improvements in academic performance, in addition, the system is also able to improve students' comprehensive language skills that show eligibility, excellence, and the operation of situational teaching of junior English with the help of multimedia [34]. AI can also be applied in student-centered mode to teach Listening and speaking to Students majoring in English. As research conducted by $\mathrm{Si} \mathrm{Wu}$ shows through the application of AI-based flipped classrooms, students have trained their ability to manage their learning and strengthen their ability to create studying plans, apply them, and reflect the effectiveness of learning [35].

The study conducted by [36] shows that an Artificial Intelligence system can make 80\% of students satisfied with the new teaching model. The quality of education, service, and information can influence highly by the satisfaction of AI in education as in the acceptance of AULA as a learning medium that offers up-to-date content and more efficient and effective services[37]. It will be possible to fully address a student's language learning and abilities with the support of intelligent assistance to a teacher's daily tasks. [38].

Changes in the digital age urge students to not only learn but also be able to take advantage of the advantages that exist today. AI attachments are considered a valuable tool, as they have the ability to develop and facilitate the completion of diagnostic processes so that each student's goals may be fulfilled by adjusting course material. [39][40][29][41]. Artificial intelligence techniques can be very helpful, as they can develop and mimic human reasoning processes and decision-making in designing teaching-learning frameworks. In addition, they can address uncertainty and facilitate the development of contexts that promote effective learning and teaching [39][42][37].

Some examples of artificial intelligence mentioned are translation websites to help with learning activities. In this case, the learner can enhance their listening, speaking, reading, and writing skills, as well as learn how to express emotions while simulating pronunciation [43]. Students, on the other hand, may not only practice their language but also verify whether it is appropriate or could be translated into the relevant text [39][44][45][40][20][46]. We may also use artificial translations decisions to select a language that suits us perfectly, a learning technique that would be more relevant, and that makes learning and living more fun and interesting. 
According to research [47], Students' abilities in vocabulary, listening, interpretation, and speech increase considerably between pre and post-test. This adaptive artificial intelligence translation can be used to assist students in processing material that they're not able to learn in class [39][48]. Thus, demonstrates a motivation among students to use AI to communicate and learn [19]. Lastly, it may be inferred that AI plays a significant role in language acquisition that expands over communication possibilities, such as giving incentives, training, and feedback. Thus it can be concluded that AI takes on roles beyond conversational opportunities such as providing motivation, instruction, and feedback for language learning [39][47][18][49][32].

\section{CONCLUSION}

Based on the results of this study, it can be stated that AI's function in learning can have an impact on a human's language quality. Students can benefit from the usage of artificial intelligence (AI) in the form of apps, websites, and other tools to help them interpret difficult words, construct a sentence, improve their writing and listening abilities, and learn other language skills. As a result, it is an important area that educational institutions may be considered the advancement of AI-based learning to enhance performance and innovation.

\section{REFERENCES}

[1] C. González García, E. Núñez-Valdez, V. García-Díaz, C. Pelayo G-Bustelo, and J. M. Cueva-Lovelle, "A Review of Artificial Intelligence in the Internet of Things," Int. J. Interact. Multimed. Artif. Intell., vol. 5, no. 4, p. 9, 2019, doi: 10.9781/ijimai.2018.03.004.

[2] M. Nagendran et al., "Artificial intelligence versus clinicians: Systematic review of design, reporting standards, and claims of deep learning studies in medical imaging," $B M J$, vol. 368, pp. 1-12, 2020, doi: 10.1136/bmj.m689.

[3] Z. Sun, M. Anbarasan, and D. Praveen Kumar, "Design of online intelligent English teaching platform based on artificial intelligence techniques," Comput. Intell., vol. 37, no. 3, pp. 1166-1180, 2021, doi: 10.1111/coin.12351.

[4] M. Woschank, E. Rauch, and H. Zsifkovits, "A review of further directions for artificial intelligence, machine learning, and deep learning in smart logistics," Sustain., vol. 12, no. 9, 2020, doi: 10.3390/su12093760.

[5] M. Y. Ali, S. Bin Naeem, and R. Bhatti, "Artificial intelligence tools and perspectives of university librarians: An overview," Bus. Inf. Rev., vol. 37, no. 3, pp. 116-124, 2020, doi: 10.1177/0266382120952016.

[6] M. Xiao and H. Yi, "Building an efficient artificial intelligence model for personalized training in colleges and universities," Comput. Appl. Eng. Educ., vol. 29, no. 2, pp. 350-358, 2021, doi: 10.1002/cae.22235.

[7] Y. M. Bah, "Corona virus (Covid- 19) and Education for All Achievement: Artificial Intelligence and Special Education Needs- Achievements and Challenges," COUNSEDU Int. J. Couns. Educ., vol. 5, no. 3, 2020, doi: 10.23916/0020200528630.

[8] R. Shrivastava and P. Mahajan, "Influence of social networking sites on scholarly communication: A study using literature in Artificial Intelligence," J. Librariansh. Inf. Sci., vol. 53, no. 3, pp. 522-529, 2021, doi: 10.1177/0961000616678309.

[9] N. M. Saravana Kumar, "Implementation of Artificial Intelligence in Imparting Education and Evaluating Student Performance," J. Artif. Intell. Capsul. Networks, vol. 01, no. 01, pp. 1-9, 2019, doi: 10.36548/jaicn.2019.1.001.

[10] P. Li, Y. Ning, and H. Fang, "Artificial intelligence translation under the influence of 
multimedia teaching to study English learning mode," Int. J. Electr. Eng. Educ., 2021, doi: 10.1177/0020720920983528.

[11] M. Naseem, R. Akhund, H. Arshad, and M. T. Ibrahim, "Exploring the Potential of Artificial Intelligence and Machine Learning to Combat COVID-19 and Existing Opportunities for LMIC: A Scoping Review," J. Prim. Care Community Heal., vol. 11, 2020, doi: 10.1177/2150132720963634.

[12] L. Ma, "An Immersive Context Teaching Method for College English Based on Artificial Intelligence and Machine Learning in Virtual Reality Technology," Mob. Inf. Syst., vol. 2021, 2021, doi: 10.1155/2021/2637439.

[13] A. Pinandito, C. P. Wulandari, D. D. Prasetya, T. Hirashima, Y. Hayashi, and H. M. Az-Zahra, "Students' acceptance towards kit-build concept map authoring tool in supporting learning of english reading comprehension," PervasiveHealth Pervasive Comput. Technol. Healthc., pp. 158-164, 2020, doi: 10.1145/3427423.3427464.

[14] Y. Bin and D. Mandal, "English teaching practice based on artificial intelligence technology," J. Intell. Fuzzy Syst., vol. 37, no. 3, pp. 3381-3391, 2019, doi: 10.3233/JIFS-179141.

[15] L. Liu and N. Peng, "Evaluation of user concentration in ubiquitous and cognitive artificial intelligence-assisted English online guiding system integrating face and eye movement detection," Int. J. Commun. Syst., vol. 34, no. 6, pp. 1-14, 2021, doi: $10.1002 /$ dac. 4580 .

[16] L. J. Moleong, Metode Penelitian Kualitatif. Bandung: PT. Remaja Rosdakarya, 2013.

[17] H. Snyder, "Literature Review as a Research Methodology: An Overview and Guidelines," J. Bus. Res., vol. 104, no. C, pp. 333-339, 2019.

[18] A. I. Saifulloh, "Pembelajaran Menterjemah Bahasa Indonesia Kedalam Bahasa Inggris Dengan Pemanfaatan Google Translate Mi Billingual Pucang Krian Sidoarjo Ahmad Iklil Saifulloh," ABDIMAS Nusant. J. Pengabdi. Kpd. Masy., vol. 1, no. 2, pp. 93-99, 2020.

[19] A. A. Yunanto and et al, "Pengembangan Aplikasi Pembelajaran Grammar Bahasa Inggris berbasis Permainan," in Seminar Nasional Terapan Riset Inovatif (SENTRINOV), 2020, vol. 6, no. 1, pp. 737-744.

[20] C. H. W. Prastiwi and N. Pujiawati, "Penggabungan Artificial Intelligence dan Kecerdasan Alami dalam Pembelajaran Keterampilan Menulis Bahasa Inggris," Pros. Semin. Nas. Pascasarj., pp. 1-7, 2019.

[21] I. Suryana, A. Asrianto, and D. Murwantono, "Artificial Intelligence To Master English Listening Skills for Non-English Major Students," J. Lang. Lang. Teach., vol. 8, no. 1, p. 48, 2020, doi: 10.33394/jollt.v8i1.2221.

[22] K. Abilowo, M. M. Santoni, and A. Muliawati, "Perancangan Chatbot Sebagai Pembelajaran Dasar Bahasa Jawa Menggunakan Artificial Intelligence Markup Language," Inform. J. Ilmu Komput., vol. 16, no. 3, p. 139, 2020, doi: 10.52958/iftk.v16i3.2010.

[23] Z. Su, L. Miao, and J. Man, "Artificial Intelligence Promotes the Evolution of English Writing Evaluation Model," IOP Conf. Ser. Mater. Sci. Eng., vol. 646, no. 1, 2019, doi: 10.1088/1757-899X/646/1/012029.

[24] D. I. Rachmawati and J. Jurianto, "Investigating English Department Students' Foreign Language Speaking Anxiety: a Case Study in Universitas Airlangga, Indonesia," Soc. Sci. Humanit. Educ. J. (SHE Journal), vol. 1, no. 2, p. 22, 2020, doi: 10.25273/she.v1i2.6624.

[25] S. D. Noviyanti, "Artificial Intelligence (AI)-Based Pronunciation Checker: An Alternative for Independent Learning in Pandemic Situation," ELT Echo J. English Lang. Teach. Foreign Lang. Context, vol. 5, no. 2, p. 162, 2020, doi: 
10.24235/eltecho.v5i2.7246.

[26] A. F. Muhammad, D. Susanto, A. Alimudin, Z. A. Rochman, M. Hasbi Assidiqi, and S. Nabhan, "Development of English Conversation Practice App with Artificial Intelligence \& Speech Recognition," IES 2020 - Int. Electron. Symp. Role Auton. Intell. Syst. Hum. Life Comf., pp. 442-449, 2020, doi: 10.1109/IES50839.2020.9231570.

[27] J. Yunjie, "Research on the practice of college English classroom teaching based on Internet and artificial intelligence," J. Intell. Fuzzy Syst., pp. 1-10, 2021, doi: $10.3233 /$ jifs-219121.

[28] B. Hamuddin, K. Julita, F. Rahman, and T. Derin, "Artificial Intelligence in EFL Context: Rising Students' Speaking Performance with Lyra Virtual Assistance," Int. J. Adv. Sci. Technol., vol. 29, no. 5, pp. 6735-6741, 2020.

[29] P. Trisna, H. Permana, N. Luh, P. Ning, S. P. Astawa, and K. Kunci, "Artificial Intelligence dalam Pengembangan Media Pembelajaran Bahasa Inggris," JIIP-Jurnal Ilm. Ilmu Pendidik., vol. 3, no. 3, pp. 687-692, 2020, [Online]. Available: http://jiip.stkipyapisdompu.ac.id.

[30] R. Wang, "Research on Artificial Intelligence Promoting English Learning Change," in 3rd International Conference on Economics and Management, Education, Humanities and Social Sciences (EMEHSS 2019) Research, 2019, vol. 325, pp. 392395, doi: 10.2991/emehss-19.2019.79.

[31] M. Sun and Y. Li, "Eco-Environment Construction of English Teaching Using Artificial Intelligence under Big Data Environment," IEEE Access, vol. 8, pp. 193955193965, 2020, doi: 10.1109/ACCESS.2020.3033068.

[32] X. Sun, "5G Joint Artificial Intelligence Technology in the Innovation and Reform of University English Education," Wirel. Commun. Mob. Comput., vol. 2021, 2021, doi: 10.1155/2021/4892064.

[33] A. A. Yunanto et al., "Penerapan Unsur Permainan pada Pengembangan Aplikasi Pembelajaran Bahasa Inggris,” JUPITER, vol. 13, no. 1, pp. 1-8, 2021.

[34] M. Qianjing and T. Lin, "An artificial intelligence based construction and application of english multimodal online reading mode," J. Intell. Fuzzy Syst., vol. 40, no. 2, pp. 3721-3730, 2021, doi: 10.3233/JIFS-189406.

[35] S. Wu and F. Wang, "Artificial Intelligence-Based Simulation Research on the Flipped Classroom Mode of Listening and Speaking Teaching for English Majors," Mob. Inf. Syst., vol. 2021, 2021, doi: 10.1155/2021/4344244.

[36] X. Zhang and L. Chen, "College English Smart Classroom Teaching Model Based on Artificial Intelligence Technology in Mobile Information Systems," Mob. Inf. Syst., vol. 2021, 2021, doi: 10.1155/2021/5644604.

[37] F. Effendy, O. D. Kurniawati, and G. Priambada, "Factor Affecting E-Learning User Acceptance: A Case Study of AULA," J. Phys. Conf. Ser., vol. 1783, no. 1, 2021, doi: 10.1088/1742-6596/1783/1/012122.

[38] H. Yu and S. Nazir, "Role of 5G and Artificial Intelligence for Research and Transformation of English Situational Teaching in Higher Studies," Mob. Inf. Syst., vol. 2021, pp. 1-16, 2021, doi: 10.1155/2021/3773414.

[39] H. Jiang, "Coastal atmospheric climate and artificial intelligence English translation based on remote sensing images," Arab. J. Geosci., vol. 14, p. 475, 2021.

[40] O. Zawacki-Richter, V. I. Marín, M. Bond, and F. Gouverneur, "Systematic review of research on artificial intelligence applications in higher education - where are the educators?," Int. J. Educ. Technol. High. Educ., vol. 16, no. 1, pp. 0-27, 2019, doi: 10.1186/s41239-019-0171-0.

[41] A. Asrifan, C. T. Zita, K. Vargheese, and M. Amir, "The effects of CALL (computer 
assisted language learning) toward the students' English achievement and attitude," $J$. Adv. English Stud., vol. 3, no. 2, pp. 94-106, 2020, [Online]. Available:

http://sastra.unifa.ac.id/journal/index.php/jes/index.

[42] V. Kavitha and R. Lohani, "A critical study on the use of artificial intelligence, eLearning technology and tools to enhance the learners experience," Cluster Comput., vol. 22, pp. 6985-6989, 2019, doi: 10.1007/s10586-018-2017-2.

[43] A. Derian Ramdhani, "PENGGUNAAN GOOGLE TRANSLATE DALAM MENUNJANG PEMBELAJARAN BAHASA INGGRIS SISWA Distance learning View project education View project," no. May, 2021, [Online]. Available: https://www.researchgate.net/publication/351711929.

[44] L. Na, "Simulation of English feature recognition based on machine learning and artificial intelligence technology," J. Ambient Intell. Humaniz. Comput., no. 0123456789, 2021, doi: 10.1007/s12652-021-03068-1.

[45] K. Rybinski and E. Kopciuszewska, "Will artificial intelligence revolutionise the student evaluation of teaching? A big data study of 1.6 million student reviews," Assess. Eval. High. Educ., vol. 46, no. 7, pp. 1127-1139, 2021, doi: 10.1080/02602938.2020.1844866.

[46] J. Siahaan and et al, Akademisi dalam Lingakaran Daring, Pertama. Tulungagung: Akademia Pustaka, 2021.

[47] R. R. Divekar* et al., "Foreign language acquisition via artificial intelligence and extended reality: design and evaluation," Comput. Assist. Lang. Learn., vol. 0, no. 0, pp. 1-29, 2021, doi: 10.1080/09588221.2021.1879162.

[48] N. L. P. N. S. P. Astawa and P. T. H. Permana, "Media Pembelajaran dengan Kecerdasan Buatan dalam Pembelajaran Bahasa Inggris Generasi-Z," J. Sains Sosio Hum., vol. 4, no. 2, pp. 756-767, 2020, doi: 10.22437/jssh.v4i2.11540.

[49] M. Arti, "Tantangan Sekolah Dan Peran Guru Dalam Mewujudkan Pembelajaran Bahasa Yang Efektif Di Era 4.0 Menuju Masyarakat 5.0," TANTANGAN Sekol. DAN PERAN GURU DALAM MEWUJUDKAN PEMBELAJARAN Bhs. YANG Ef. DI ERA 4.0 MENUJU Masy. 5.0 Mesi, vol. 18, pp. 1027-1036, 2020. 